\title{
STRIKING A BALANCE: \\ EXTENDING MINIMUM RIGHTS TO U.S. GIG ECONOMY WORKERS BASED ON E.U. DIRECTIVE 2019/1153 ON Transparent ANd Predictable Working Conditions
}

\author{
LAUREN M. THOMPSON ${ }^{*}$
}

\section{INTRODUCTION}

You have probably downloaded at least one app on your phone that could connect you to a person who will provide you with a service in less than an hour. With a few touches of the screen, you can summon a driver to give you a ride to the airport, you can ask a person to deliver food to your door, or you can even pay someone to pick up your laundry. In the past decade, there has been a proliferation of companies that manage online platforms or "virtual marketplaces" to connect people who need services with workers who can quickly perform those services.

Companies that utilize online platforms to facilitate a connection between worker and consumer have become ubiquitous in our lives and our culture. The popular rideshare companies, Uber and Lyft, and the food delivery service, Grubhub, are publicly traded on the New York Stock Exchange. ${ }^{1}$ In Spring 2019, 20th Century Fox released a movie called Stuber, the plot of which centered around an Uber driver. ${ }^{2}$ The grocery delivery service, Instacart, has partnerships with grocery stores like Kroger, ALDI, Publix, and HyVee. ${ }^{3}$ Not only do these companies permeate American culture, but they also contribute to the U.S. labor force. A 2018 Gallup Paper concluded that $36 \%$ of U.S. workers "have a gig work arrangement in some capacity." This means that one in three workers has some form of short-term, flexible work arrangement, often mediated by an online

* J.D. Candidate, 2021, Indiana University Robert H. McKinney School of Law; M.A., 2012, DePaul University; B.A., 2010, Purdue University. I would like to thank the Indiana International \& Comparative Law Review staff for the tremendous effort in reviewing and editing this Note. Additionally, I would like to thank Professor James Nehf for the outstanding and invaluable feedback he provided throughout the writing process. I would also like to thank my friends and family for their unending love and support throughout the creation of this Note.

1. Uber Technologies Inc., N.Y.STOCK EXCH., https://www.nyse.com/quote/ XNYS:UBER [https://perma.cc/7C63-N7XC] [hereinafter Uber]; Lyft, Inc, N.Y. STOCK EXCH., https://www.nyse. com/quote/XNGS:LYFT [https://perma.cc/M2TG-F5MX] [hereinafter Lyft]; Grubhub, Inc., N.Y. STOCK EXCH., https://www.nyse.com/quote/XNYS:GRUB [https://perma.cc/UB66-RBN5] [hereinafter Grub].

2. Stuber, IMBD, https:/www.imdb.com/title/tt7734218/?ref_=fn_al_tt_1 [https://perma.cc/ $\mathrm{SD} 2 \mathrm{~F}-\mathrm{NUFB}]$.

3. Which Retailers are Using Instacart?, CBinsights: Res. Briefs (Oct. 16, 2018), https://www.cbinsights.com/research/instacart-retailer-grocer-partners/ [https://perma.cc/CM44$5 \mathrm{X} 7 \mathrm{X}]$.

4. Gallup, The Gig Economy and Alternative Work Arrangements 2 (2018). 
virtual marketplace. ${ }^{5}$

The innovations made by virtual marketplace companies (VMCs) offer many benefits to society. Consumers benefit from quick and accessible services, reduced prices, and increased competition in the marketplace. ${ }^{6}$ Workers benefit from flexible work arrangements, the ability to choose their projects, and the ability to earn income through more than one source. ${ }^{7}$ Yet, with the advent of novel work relationships comes many challenges and unanswered questions. One of the most pressing questions is whether, and how, workers who participate in the gig economy will be granted job protections.

The nature of gig economy jobs means that workers do not have formal contracts that lay out hours or wages. ${ }^{8}$ Workers sign agreements in which they are paid for each gig after the performance of the task. ${ }^{9}$ This allows flexibility, but it also leaves workers in a vulnerable position. Workers do not always know how much they will be compensated, and confusing algorithms can serve to obfuscate a workers' actual earnings. ${ }^{10}$ The employment status of gig economy workers is also ambiguous. There is no clear answer on whether gig economy workers are employees or independent contractors. ${ }^{11}$ The status of a worker often depends on the jurisdiction that she lives in and the specific facts of the employment relationship. ${ }^{12}$ This lack of clarity can lead to abuses like unreasonable restrictions, employment misclassifications, and unpredictable work hours. ${ }^{13}$

As the gig economy began to expand in Europe in the 2010s, the European Union (E.U.) recognized the need to conduct economic and policy research to

5. Id. at 6 .

6. The Disrupter Series: How the Sharing Economy Creates Jobs, Benefits Consumers, and Raises Policy Questions: Hearing Before the Subcomm. on Commerce, Mfg., and Trade of the H. Comm. on Energy and Commerce, 114th Cong. 14 (2015) [hereinafter The Disrupter Series] (statement of Michael Beckerman, President \& CEO, Internet Assoc.).

7. Megan Hansen, Who Benefits from the Gig Economy? JAMES MAdison Inst. (Mar. 14, 2019), https://www.jamesmadison.org/who-benefits-from-the-gig-economy/ [ https://perma.cc/ JQ4Y-T4HL].

8. See generally Lyft Driver Addendum, LYFT, https://www.lyft.com/terms/driver-addendum (last updated Aug. 26, 2019) [https://perma.cc/E8NB-AXNM].

9. Id.

10. See Jessica Suriano, 'Honestly The Apps Pay You Dirt': Inside the Fight for Digital Delivery Workers' Rights, MTV News (Aug. 27, 2019), http://www.mtv.com/news/3136788/ honestly-the-apps-pay-you-dirt-inside-the-fight-for-digital-delivery-workerss-rights/ [https://perma.cc/T83N-YSMC].

11. Steven Chung, In The Gig Economy, Who Is an Employee and Who is an Independent Contractor?, ABOvE THE LAW (Oct. 2, 2019), https://abovethelaw.com/2019/10/in-the-gigeconomy-who-is-an-employee-and-who-is-an-independent-contractor/ [https://perma.cc/ZYC56RQ8].

12. Id.

13. See Veena B. Dubal, Winning the Battle, Losing the War?: Assessing the Impact of Misclassification Litigation on Workers in the Gig Economy, 2017 WIS. L. REV. 7 39,745-46; O’Connor v. Uber Techs., Inc., 2019 U.S. Dist. LEXIS 54608, 2019 WL 1437101. 
understand the impact this new employment relationship would have on the economy and workers. ${ }^{14}$ They began to develop a European Agenda on the Collaborative Economy. ${ }^{15}$ This policy research helped to formulate Directive 2019/1152 on Transparent and Predictable Working Conditions in the European Union. ${ }^{16}$

The United States should also be proactive in preserving the benefits of the gig economy while protecting workers by enacting a federal mandate with provisions similar to E.U. Directive 2019/1152. The mandate should have four main components. First, it should require companies to be transparent about all forms of remuneration. Second, it should require companies to be clear and upfront about the nature of the employment relationship. Third, it would stipulate measures to prevent abuse of atypical gig economy contracts. Fourth, it would expand on the E.U. Directive to put workers in a more favorable position by covering both employees and independent contractors, putting the burden of proof on the employer to show that the worker is an independent contractor, and outline clear penalties for violations of the mandate.

\section{THE HISTORY OF THE GIG ECONOMY IN THE UNITED STATES AND EUROPE}

There are many different names for an emerging market that hinges on virtual marketplaces that match customers with service providers who complete temporary tasks or gigs. ${ }^{17}$ It is nebulous and goes by different names like the "collaborative economy," "sharing economy," or "gig economy." ${ }^{18}$ Tina Brown coined the term "gig economy" in 2009 when she noticed that none of her friends had jobs anymore. They had "gigs," which she described as many "free-floating

14. See Communication from the Commission to the European Parliament, The Council, The European Economic and Social Committee and The Committee of the Regions - A European Agenda for the Collaborative Economy, at 15, COM (2016) 356 final (Feb. 6, 2016) [hereinafter Communication].

15. Id. This Communication and other E.U. documents use the term "collaborative economy" to "refer[] to business models where activities are facilitated by collaborative platforms that create an open marketplace for the temporary usage of goods or services often provided by private individuals." Id. at 3.

16. See Council Directive 2019/1152 of June 20, 2019 on Transparent and Predictable Working Conditions in the European Union, O.J. (L 186).

17. Dubal, supra note 13, at 740, 742; James Duggan et al., The Rise and Rise of the Gig Economy, RTE(June 2, 2018, 9:41 AM), https://www.rte.ie/brainstorm/2018/0530/967082-the-riseand-rise-of-the-gig-economy/[https://perma.cc/FA4R-VV2B].

18. See Inara Scott \& Elizabeth Brown, Redefining and Regulating the New Sharing Economy, 19 U. PA. J. Bus. L. 553, 554 (2017); Jacob Morgan, Why the Collaborative Economy is Changing Everything, ForBes (Oct. 16, 2014, 12:09 AM), https:/www.forbes.com/sites/ jacobmorgan/2014/10/16/why-the-collaborative-economy-is-changing-everything/ ?sh=64dd5a6928a1 [https://perma.cc/J9P3-RK3Y]; Tina Brown, The Gig Economy, ThE DAILY BEAST (Jan. 12, 2009, 12:34 AM, updated July 14, 2017), https://www.thedailybeast. com/the-gigeconomy [https://perma.cc/5BHV-PBRE]. 
projects, consultancies, and part-time bits and pieces they try and stitch together . . . to hang on to the apartment, the health-care policy, the baby sitter, and the school fees." 19 Throughout this Note, I will borrow Tina Brown's terms and use "gig economy," "gig economy workers," and "gig work" because my focus is on the workers who perform the "gigs" that drive the market.

The gig economy is an emerging labor force, and there are still uncertainties around how to define it and which workers should be encompassed within it. ${ }^{20}$ What does a gig worker look like? Is a periodic babysitter or a freelance graphic designer part of the gig economy? Often, the gig economy is conceived as a labor market characterized by short-term tasks facilitated by a virtual marketplace. This is the iteration of the gig economy that I will address here. Short-term temporary work is far from a new phenomenon. Yet, the explosive rise of tech companies that facilitate gig interactions has changed the way we think about the gig economy. ${ }^{21}$ Although the numbers are difficult to pin down, as much as $7 \%$ of U.S. workers, and between $9.5 \%$ to $11 \%$ of workers in European countries, participate in the gig economy via virtual marketplaces. ${ }^{22}$

\section{A. The History of Gig Work}

Most people think of a job as a long-term assignment with regular 9-to-5 hours in the same location and with the same company. However, this modern concept of a job did not take hold until after the industrial revolution. In the eighteenth century, it was common for middle-class people to perform various short-term jobs. Oxford Historian, Tawny Paul, found that British men in the early eighteenth century often held many different jobs. For example, Edmund Harrold, a barber in Manchester, "rented a small shop, shaved customers' heads, bought and sold hair, and crafted wigs. In the hours unfilled by this he worked as a book dealer, and eventually as an auctioneer, selling various items in alehouses." 23

The industrial revolution normalized regular, long-term work, but the practice of short-term, temporary work was not extinguished. ${ }^{24}$ In the United States, short-

19. Scott \& Brown, supra note 18 .

20. Aditi Shrikant, The Gig Economy Isn't Going Anywhere. 4 Experts Explain Why, Vox (Oct. 1, 2018, 4:00 PM), https://www.vox.com/the-goods/2018/10/1/17924856/gig-economy-ubersharing [https://perma.cc/RD5F-CQ22].

21. Tawny Paul, The Gig Economy Is Nothing New-It Was Standard Practice in the 18th century (Jul 19, 2017, 9:40 AM), https://www.businessinsider.com/the-gig-economy-is-nothingnew-2017-7 [https://perma.cc/G6DS-JPUJ].

22. Gallup, supra note 4, at 5; A. Pesole, M.C. Urzí Brancati, \& E. Fernández-Macías, New Evidence on Platform Workers in Europe, EUR. COMM'N, JRC SCI. FOR POL'Y REP. 14 (2020), https://publications.jrc.ec.europa.eu/repository/bitstream/JRC118570/jrc118570_jrc118570_fina 1.pdf [https://perma.cc/XY55-QPKT].

23. Paul, supra note 21.

24. Shelley Strom, A Brief History of the Gig Economy, LivEOPS, https://www.liveops.com/ blog/brief-history-gig-economy/ [ https://perma.cc/5G55-Q5NM]. 
term, seasonal, temporary, and freelance work or "gigs" remained prevalent into the late twentieth century. ${ }^{25}$ In 1995, the Bureau of Labor Statistics found that $10 \%$ of the overall workforce was in "alternative employment arrangements," meaning they were independent contractors, on-call workers, or hired through contract firms or temporary help agencies. ${ }^{26}$ Ten years later, this number remained mostly the same at $10.7 \%{ }^{27}$ A 2018 paper published by Gallup found that $36 \%$ of workers in the U.S. had some kind of "alternative work arrangement." 28

Even though the percentage of people who engage in alternative work arrangements has risen significantly in the past twenty years, short-term, temporary work arrangements are not new. ${ }^{29}$ What is new, is that the internet has facilitated the growth of virtual marketplace companies or a "web of companies" that "utilize web technology-serves as the readily accessible meeting ground offering the performance of services by connecting workers to hirers to perform them." ${ }^{30}$

\section{B. The Launch of the Gig Economy}

The first company to facilitate peer-to-peer interactions through the internet, Craigslist, launched in 1996. Craigslist was essentially an online version of the classified ads. It was innovative because it was the first online platform through which workers could post their availability to perform short-term jobs or "gigs," and people looking for services could hire them. ${ }^{31}$ Craigslist provided a forum, but gig-seekers still had to take the initiative to post their services, communicate with customers, and arrange logistics and payment. It would be another decade before companies had the idea and technological capacity to shift the logistical work to digital platforms.

In August 2008, Brian Chesky and Joe Gebbia launched the virtual marketplace company (VMC) Airbnb (known as "AirBed and Breakfast" at the time. $)^{32}$ Where Craigslist acted as a local marketplace for anything from car parts to job postings, Airbnb focused specifically on matching "hosts" who had extra space to left with travelers from all over the world looking for a place to stay. ${ }^{33}$

25. Id.

26. The State of American Jobs, Pew Res. Ctr.: Social \& Demographic Trends (Oct. 6, 2016), https://www.pewsocialtrends.org/2016/10/06/1-changes-in-the-american-workplace/ [https:// perma.cc/V4RN-2FH6].

27. Id.

28. GALLUP, supra note 4.

29. Strom, supra note 24.

30. Orly Lobel, The Gig Economy \& The Future of Employment and Labor Law, 51 U.S.F. L. REV. 51, 51 (2017).

31. Strom, supra note 24.

32. The History of the Gig Economy, William Jessup U. OnLine (Oct. 23, 2018), https:// online.jessup.edu/blog/business/history-of-the-gig-economy/ [https://perma.cc/2NF7-8LY7].

33. About Us, AIRBNB NEws, https://news.airbnb.com/about-us/ [https://perma.cc/EUC6- 
In March 2009, Airbnb grew to ten thousand users and twenty-five hundred listings. ${ }^{34}$ In the same month, Garrett Camp, Oscar Salazar, and Conrad Whelan built the first version of the Uber app (called UberCab) with Travis Kalanick serving as an advisor of the company. ${ }^{35}$ The goal of the company was to lower the cost of "black-car service" by utilizing location data to match drivers with passengers. ${ }^{36}$ In 2012, Uber had to contend with the launch of Lyft, a competing ride-share company. ${ }^{37}$ Once the idea of using data and online platforms to facilitate peer-to-peer transactions took off, these companies expanded at a rapid pace. $^{38}$ By September 2015, Airbnb had seven million users and 1.5 million listings. ${ }^{39}$ By the end of 2016, Uber was available in five hundred cities and had 480 million riders annually, and Lyft served 160 million riders annually. ${ }^{40}$

Virtual Marketplace Companies (VMCs) proved to be very popular with consumers, and in less than a decade, dozens of companies (like TaskRabbit (2008), Postmates (2011), Rover (2011), DoorDash (2013), Wag (2015), etc.) sprang up. The companies provide different kinds of services, but each is built around the same innovative business model. In this model, the company creates and manages an app, which utilizes a proprietary algorithm to connect service providers with consumers. The VMC also manages payments and logistics to make the experience quick, secure, and efficient.

This tech-savvy business model, and the success of the companies, excited and attracted investors. ${ }^{41}$ By 2015 , the ride-sharing company, Uber, had raised $\$ 10$ billion from venture capitalists in Silicon Valley. ${ }^{42}$ Uber's relatively small competitor, Lyft, raised $\$ 1$ billion in 2016, which included a $\$ 500$ million investment from General Motors. ${ }^{43}$ The success of a VMC depends on innovative

ZPJF].

34. Jean Folger, Airbnb: Advantages and Disadvantages, Investopedia (last updated Apr. 6, 2020), https:/www.investopedia.com/articles/personal-finance/032814/pros-and-cons-usingairbnb.asp\#: :text=Airbnb\%20is $\% 20$ an $\% 20$ online $\% 20$ marketplace,from $\% 20 \%$ E2 $\% 80 \% 9 \mathrm{Cair} \%$ 20mattress\%20B\%26B.\%E2\%80\%9D [https://perma.cc/F4LX-9RN5].

35. Nathan McAlone, Here's How Uber Got Its Start and Grew to Become the Most Valuable Startup in the World, Bus. INSIDER (Sept. 13, 2015, 8:00 AM), https://www.businessinsider.com/ history-of-uber-and-its-rise-to-become-the-most-valuable-startup-in-the-world-2015-9 [https://perma.cc/M7F9-F747].

36. The History of the Gig Economy, supra note 32.

37. Id.

38. Id.

39. Id.

40. Id.

41. Stephane Vita, The Companies That Are Funding Uber and Lyft, InVESTOPEDIA (June 25, 2019), https://www.investopedia.com/articles/markets/011516/companies-are-funding-uber-andlyft.asp [https://perma.cc/Z6AD-WL2B].

42. $I d$.

43. Heather Somerville, Lyft Lands $\$ 600$ Million in Fresh Funding; Company Valued at 7.5 Billion, REUTERS (Apr. 11, 2017, 4:03 PM), https://www.reuters.com/article/us-lyft-funding-idUSK BN17D2I8 [https://perma.cc/Y8LA-RQEG]. 
technology, investors, consumers, and another crucial component- workers. $^{44}$ VMC's match consumers with workers; therefore, for each gig or task requested by a consumer, there must be a worker willing to perform it.

\section{The Expansion of the Gig Economy in Europe}

After experiencing meteoric growth and garnering huge investments in the United States, VMCs quickly expanded into Europe. From the beginning, the companies faced more resistance on the continent of Europe than they had in the United States. Uber launched international operations in Paris in conjunction with the LeWeb international internet conference in June 2011. ${ }^{45}$ The company moved into the United Kingdom with the goal of being fully operational in time for the 2012 London Olympics. Also, in 2012, Airbnb announced that it had facilitated five million bookings, $75 \%$ of which involved international guests or hosts. ${ }^{46}$ The company increased its international presence by setting up offices in major European cities like London, Hamburg, Copenhagen, Paris, Milan, Barcelona, and Moscow. ${ }^{47}$ TaskRabbit expanded into the international market in 2013 when it opened an office in London. ${ }^{48}$

One of the reasons these companies opened offices "on the ground" in European cities was to recruit local workers. ${ }^{49}$ Richard Howard, the first local employee that Uber hired in London, was tasked with recruiting drivers. ${ }^{50}$ Howard "focused on what he was good at, which was getting skeptical drivers into the office, showing them how Uber worked and giving them a free iPhone." His task was complicated by the fact that Uber already faced competition in London, such as the British rideshare service, Hailo. ${ }^{52}$ Other U.S. companies faced competition from locally-grown VMCs when they entered the European

44. See Dr. Emilia Istrate \& Jonathan Harris, The Future of Work: The Rise of the Gig Economy, NAT'L AsS'N COUNTIES (Nov. 2017), https://www.naco.org/featured-resources/futurework-rise-gig-economy [https://perma.cc/2LBB-DJVC].

45. Alexia Tsotsis, Uber Launches Its First International Efforts in Paris, TECHCRUNCH (Dec. 5, 2011, 7:06 AM), https://techcrunch.com/2011/12/05/uber-launches-its-first-internationalefforts-in-paris/ [https://perma.cc/6M4Q-QWRH].

46. Airbnb: 5 Million Nights Booked, Opening 6 New International Offices in Q1 2012, TECHCRUNCH (Jan. 26, 2012 8:59 AM), https:/techcrunch.com/2012/01/26/airbnb-5-millionnights-booked-opening-6-new-international-offices-in-q1-2012/ [https://perma.cc/E2WL-RAUU].

47. Id.

48. Katie Collins, TaskRabbit Online Marketplace for Chores and Errands Arrives in the U.K., WIRED (Nov. 22, 2013), https://www.wired.co.uk/article/taskrabbit [https://perma.cc/UH4M$\mathrm{XS} 2 \mathrm{H}]$.

49. See Sam Knight, How Uber Conquered London, The Guardian (Apr. 27, 2016, 1:00 AM), https://www.theguardian.com/technology/2016/apr/27/how-uber-conquered-london [https://perma.cc/56KA-W4TT].

50. Id.

51. Id.

52. Id. 
market. ${ }^{53}$ The German ride-sharing service, Mytaxi, was well established in Germany by 2011 and had expanded into Vienna, Barcelona, Zurich, and Warsaw by $2012 .{ }^{54}$ Taskrabbit faced local competition before it even opened its first international office in London with companies, like TaskPandas and Sorted, which brazenly borrowed its business model. ${ }^{55}$

Competition with other companies was not the only challenge that VMCs faced in Europe. Ridesharing apps had to contend with the fact that most major European cities had robust taxi services and unions. ${ }^{56}$ Drivers of the iconic London black cabs, "have to study for about three years to pass the Knowledge of London test.. ${ }^{, 57}$ When Uber first landed in Europe, it was branded as a luxury car service through which those with moderate incomes could get a taste of life with their own private driver - even if it was just for one trip. ${ }^{58}$ As the app was gaining traction in London, Uber Executives launched a pilot program in San Francisco for a budget rideshare service called UberX.$^{59}$ Uber continued on as a luxury brand in London, but within a year the wildly successful UberX migrated to London. ${ }^{60}$

Taxi associations began to recognize the threat posed by UberX. Licensed taxi drivers were subject to many safeguards and regulations that Uber drivers could avoid, i.e., criminal background checks, medical checks, being wheelchair accessible, and passing a knowledge test. ${ }^{61}$ In June 2014, tensions bubbled over and cab drivers in London protested against this regulatory disparity, "Trafalgar Square and Whitehall were jammed from the start of the planned 'go slow' at $2 \mathrm{pm}$, as thousands of black cabs gathered honking their horns, bringing total gridlock to the cent[er] of the capital." ${ }^{.2}$

English taxi associations were joined by drivers protesting in Paris, Madrid,

53. Steve O'Hear, While TaskRabbit Ponders UK Launch, Two Local Competitors Emerge: TaskPandas and Sorted, TECHCRUNCH (Dec. 6, 2012, 4:30 AM), https://techcrunch.com/2012/ 12/06/you-silly-rabbit/ [https://perma.cc/E2D5-5GKK].

54. About mytaxi, MYTAXI, https://us.mytaxi.com/jobs/about-mytaxi.html [https://perma.cc/ Z9T5-URUS].

55. O'Hear, supra note 53.

56. Susanne Pernicka, The Disruption of Taxi and Limousine Markets by Digital Platform Corporations in Western Europe and the United State: Responses of Business Associations, Labor Unions, and Other Interest Groups, INST. FOR RES. ON LABOR \& EMP'T (2019) https://irle.ucla. edu/wp-content/uploads/2019/06/Disruption-of-Taxi-and-Limousine-Markets.pdf [https://perma.cc/ 8H6L-FD79].

57. Pernicka, supra note 56.

58. Knight, supra note 49.

59. Id.

60. Id.

61. Alexandra Topping et al., Angry Cab Drivers Gridlock Europe in Protest at 'Unregulated' Taxi App, The GuARDiAn (June 11, 2014, 3:20 PM), https://www.theguardian. com/uk-news/2014/jun/1 1/cab-drivers-europe-protest-taxi-app-uber-london-madrid [https://perma.cc/WAR6-3CXP].

62. Id. 
Barcelona, Berlin, Milan, and Rome. ${ }^{63}$ Some of the largest protests took place in France in $2015 .{ }^{64}$ These protests caused gridlock on the streets and clashes with police. "Altogether, nearly 3,000 taxi drivers participated in the strike nationwide ... there were at least eight arrests in Paris and eight in Lyon . . there were 10 arrests, seven officers were hurt and 70 vehicles damaged." ${ }^{65}$ Some countries wanted to avoid non-regulated drivers from ferrying passengers imposed regulations.$^{66}$ In 2014, for example, a Belgian Court declared UberPop unlawful and threatened to fine the company $€ 10,000$ (approximately $\$ 12,118.24$ ) for any ride offered ${ }^{67}$ Other countries imposed restrictions rather than outright bans. France and Spain implemented a required fifteen-minute wait between when a ride was requested and a rideshare app driver could pick-up the passenger. ${ }^{68}$ This restriction caused Uber to suspend ridesharing services in Barcelona. ${ }^{69}$

The backlash against ridesharing apps was largely fueled by resistance from taxi drivers, associations, and unions, but other types of VMCs faced criticism as well. Citizens and activists in European cities argued that app-based vacation rental services, like Airbnb, exacerbate the cost of living and housing shortage problems. $^{70}$ Ten European cities petitioned the European Union to address the issue of short-stay vacation platforms. ${ }^{71}$ The cities wrote, "Many suffer from a serious housing shortage. Where homes can be rented out more lucratively to tourists, they vanish from the traditional housing market." 72 The city of Palma de Mallorca in Spain voted to ban listings for short-stay vacation platforms after an increase in lettings caused a $40 \%$ increase in residential rent. ${ }^{73}$ Many other cities require licenses for letting space and dole out huge penalties to short-stay vacation platforms that list rental properties lacking a license. ${ }^{74}$

\section{Id.}

64. Alissa J. Rubin and Mark Scott, Clashes Erupt Across France as Taxi Drivers Protest Uber, N.Y. TIMES (June 25, 2015), https:/www.nytimes.com/2015/06/26/business/international/ uber-protests-france.html?auth=login-google [https://perma.cc/5DYA-HXQB].

65. Id.

66. See Steve Dent, Belgium Bans Uber, Threatens $€ 10,000$ Fine for Each Attempted Pickup, ENGADGET (Apr. 15, 2014), https://www.engadget.com/2014/04/15/belgian-uber-ban-10k-fines/ [https://perma.cc/R3FQ-GEMV].

67. See id.

68. Uber Services Suspended in Barcelona, BBC News (Jan. 31, 2019), https://www. bbc.com/news/business-47071710 [https://perma.cc/CRD6-DFL7].

69. Id.

70. Jon Henly, Ten Cities Ask EU for Help to Fight Airbnb Expansion, The GuARdian (June 20, 2019, 8:51 AM), https://www.theguardian.com/cities/2019/jun/20/ten-cities-ask-eu-for-help-tofight-airbnb-expansion [https://perma.cc/82W5-FYH5].

71. Id.

72. $I d$.

73. Id.

74. Feargus O'Sullivan, Europe's Crackdown on Airbnb, CITYLAB (June 20, 2016), https:// www.citylab.com/equity/2016/06/european-cities-crackdown-airbnb/487169/ [https://perma.cc/Y3 89-YH3F]. 


\section{The Scope of Gig Economy Labor}

The percentage of U.S. workers who participate in the gig economy is between one and seven percent. However, it is difficult to determine how many U.S. workers participate in the gig economy. Government sources and private research groups came up with varied estimates. ${ }^{75}$ This difficulties stem from three different issues. First, researchers have yet to reach a consensus on how to define the gig economy and who should be encompassed within it. ${ }^{76}$ Second, researchers have struggled to come up with questions to probe gig work that do not confuse respondents. ${ }^{77}$ Third, people drop out of the gig economy at a rapid pace. ${ }^{78}$

The Bureau of Labor Statistics (the "BLS") does not currently include a category for "gig economy worker" in any of its surveys. ${ }^{79}$ The closest equivalent to "gig economy workers" that the BLS gathers data on are "contingent workers." $" 80$ The BLS periodically appends a set of questions, known as the Contingent Worker Supplement (the "CWS"), to the Current Population Survey. ${ }^{81}$ Contingent workers are, "those who do not have an implicit or explicit contract for ongoing employment" and those who report that their work is temporary. ${ }^{82}$ The BLS does not include those who have the option for long-term employment but choose temporary jobs for personal reasons as contingent workers. ${ }^{83}$ In the

75. Elisabeth Buchwald, The Government Has No Idea How Many Gig Workers There Are, and That's a Problem, MARKeTwATCH (Jan. 7, 2019, 3:51 PM), https://www.marketwatch.com/ story/the-government-has-no-idea-how-many-gig-workers-there-areheres-why-thats-a-problem2018-07-18 [https://perma.cc/BPY3-BRZL].

76. $I d$.

77. Monthly Labor ReV., Electronically Mediated Work: New Questions in the Contingent Worker Supplement, U.S. BuREAU OF LABOR StaTS. (September, 2018), https://www.bls.gov/ $\mathrm{opub} / \mathrm{mlr} / 2018 /$ article/electronically-mediated-work-new-questions-in-the-contingent-workersupplement.htm [https://perma.cc/Z3WZ-SJMF].

78. Alison Griswold, People Are Getting Sick of Working in the "Sharing” Economy, QUARTZ (Nov. 15, 2016), https://qz.com/837237/people-are-getting-sick-of-working-in-thesharing-economy/ [https://perma.cc/VPF2-R7M2].

79. Buchwald, supra note 75.

80. Id.

81. Monthly Labor Rev., supra note 77. The Current Population Survey (CPS) is a monthly study of the national labor force. About the Current Population Survey, U.S. CENSUS BurEAU, https://www.census.gov/programs-surveys/cps/about.html [https://perma.cc/66EM-TTPG].

The Contingent Worker Supplement (CWS) was first appended to the CPS in 1995. Economic News Release, U.S. Bureau of LABOR StATS. (June 7, 2018, 10:00 AM), https://www.bls.gov/ news.release/conemp.nr0.htm [https://perma.cc/F7HJ-UC6Q]. The CWS was subsequently included in the CPS in 1997, 1999, 2001, 2005, and 2017. Id. The more than 10-year gap between when the survey was administered in 2005 and 2017 raises additional questions about the reliability of the data.

82. Economic News Release, supra note 81.

83. Id. 
2017 CWS, the BLS found that, by the broadest measure, there were 5.9 million contingent workers, which made up $3.8 \%$ of all U.S. workers. ${ }^{84}$

However, BLS data does not fully encompass the breadth of gig economy workers. First, the BLS does not count those who are in a temporary position by choice as contingent workers. ${ }^{85}$ Many gig economy workers choose to take on temporary work. Indeed, flexibility and self-determination are some of the major selling points of a gig economy job. ${ }^{86}$ Next, the CWS focuses on the person's main job. ${ }^{87}$ Researchers pointed out that "The wording of the survey's employment questions may not adequately cue respondents to report work activity outside of a conventional job or business." ${ }^{18}$ Many gig economy workers take on gig work as a way to earn supplemental income on top of their full-time jobs. ${ }^{89}$ Therefore, respondents who participate in the gig economy may not report their gig work because they don't think of it as a traditional job. ${ }^{90}$ In these ways, the CWS is an imperfect measure of the number of people who are gig economy workers.

The Federal Reserve's 2017 Report on the Economic Well-Being of U.S. Households concluded that $31 \%$ of adults participated in the gig economy. The wide difference between the Bureau of Labor statistic's estimates and the Federal Reserve's estimate can mostly be attributed to the fact that the Federal Reserve has a much broader definition of a gig economy worker. The Federal Reserve's definition includes workers who perform "offline service activities, such as childcare or house cleaning; offline sales, such as selling items at flea markets or thrift stores; and online services or sales, such as driving using a ride-sharing app or selling items online." ${ }^{91}$

The researchers found that $16 \%$ of gig economy workers participated in online activities. ${ }^{92}$ This subset of workers roughly fits into my definition of the gig economy - a labor market characterized by virtual marketplaces that facilitate

84. The BLS survey defines contingent workers as those who expected their jobs to be temporary. Id. Their broadest definition of contingent workers are those who do not expect their job to last, which includes "wage and salary workers" who expect to hold their job for at least one additional year and independent contractors who expect their employment to last for one year or less. $I d$.

85. Id.

86. See The Disrupter Series, supra note 6 (statement of Luceele Smith, Driver/Partner, Uber Technologies, Inc.).

87. Economic News Release, supra note 81.

88. Katharine G. Abraham \& Ashley Amaya, Probing for Informal Work Activity, 35 J. OfF. STAT. 487, 487 (2019).

89. See Lobel, supra note 30, at 57.

90. Abraham \& Amaya, supra note 88, at 488.

91. Report on the Economic Well-Being of U.S. Households in 2017-May 2018, BOARD OF GOvernORS OF THE FED. RES. SYS., https:/www.federalreserve.gov/publications/2018-economicwell-being-of-us-households-in-2017-employment.htm (last updated June 19, 2018) [https://perma. cc/A3Z7-B8D5] [hereinafter BOARD OF GOVERNORS].

92. Id. 
a connection between worker and consumer. However, the Federal Reserve does not differentiate between online services and online sales. We must consider the fact that part of this $16 \%$ of workers utilize online platforms, like eBay or Etsy, to sell items.

In 2018 , Gallup released a paper that concluded, " $36 \%$ of all U.S. workers participate in the gig economy in some capacity." ${ }^{93}$ However, this number illustrates the fact that estimates of how many people work in the gig economy depend a lot on how the researcher conceptualizes gig economy work. Gallup defines a gig worker as any worker who does not have a "traditional, long-term employee-employer relationship." 4 This includes people who do freelance work, online platform workers, and contingent workers. ${ }^{95}$ Gallup clarifies that online platform workers make up $7 \%$ of all U.S. workers. ${ }^{96}$

There are not only technical difficulties in measuring the scope of the gig economy but logistical ones as well. Gig economy workers have an extremely high turnover rate. This turnover rate can be attributed to workers trying out different apps to see which ones can make them the most money, a strong labor market, and decreasing rates of pay from gig work. ${ }^{97}$ It is unclear what the exact turnover rate is for the gig economy. Micah Rowland, Chief Operating Officer for Fountain, a company that assists in the hiring process for gig companies, estimates that some companies he has worked with have a turnover rate of $500 \%$ each year. ${ }^{98}$

The fact that workers drop in and out of gig economy jobs at such a fast pace complicates the ability of researchers to form concrete estimates on the number of people who participate in the gig economy. The number of people working can change dramatically from year-to-year or even month-to-month. ${ }^{99}$ Despite the difficulties involved in measuring the scope of the gig economy, we know that a significant number of U.S. workers have participated in the gig economy in some way. Data suggests that a similar percentage of workers in E.U. Member States have as well.

Researchers in Europe have faced the same issues in attempts to measure the number of gig economy workers as U.S. researchers. The estimates of the percentage of the total adult population that are part of the gig economy in European countries ranges from $6 \%$ in Finland to $10 \%$ in the U.K. Researchers found that "The share of adults that have ever done some work via online platform is slightly above $10 \%$ in the UK, Spain, Germany and Portugal, and around 7\% or lower in France, Sweden, Hungary, Slovakia and Finland, with the

93. GALLUP, supra note 4.

94. Id.

95. Id.

96. Id.

97. See Christopher Mims, In a Tight Labor Market, Gig Workers Get Harder to Please, WALL ST. J. (May 4, 2019), https://www.wsj.com/articles/in-a-tight-labor-market-gig-workers-getharder-to-please-11556942404 [https://perma.cc/94UA-3QKY].

98. Id.

99. Id. 
other countries in between."100

\section{CHALLENGES WORKERS FACE IN THE GIG ECONOMY}

The gig economy has opened the door for innovative new tech companies. These companies manage online platforms that make it quick and easy for workers to take on flexible, short-term assignments. In 2016, Uber aired a national commercial encouraging people to "get your side hustle on." touted the idea of a side-hustle (a side job or gig someone takes on for extra money) as a big selling point for signing-up to drive for them. ${ }^{102}$ Advertising copy for the company boasted, "Uber is a fun, new way to make extra money that works around your schedule and current job. Drive anytime, as much or as little as you want-it's up to you." ${ }^{03}$ Flexibility and the ability to make extra money are major benefits of gig economy jobs.

In a hearing before the Subcommittee on Commerce, Manufacturing, and Trade of the House Committee on Energy and Commerce in September 2015, Luceele Smith spoke about her experience working as a driver for Uber. She testified that

What I like most about Uber is the flexibility. It allows drivers to make money on their own time. I don't have a boss to report to. I don't have to be on call. I work when I want to, for as long as I want to, or as little as I want to. ${ }^{104}$

While many workers, like Luceele Smith, have benefited from gig economy jobs, others have found that reality does not always live up to expectations. ${ }^{105}$

\section{A. How Much Are Gig Workers Paid?}

It is often difficult for workers to determine what their take-home pay will be. The "base pay" workers receive depends on each company's policy. Many companies, like Uber and Doordash, stipulate a guaranteed minimum pay per hour or per order. ${ }^{106}$ The companies rely on sophisticated algorithms that take

100. Urzi Brancati et al., New Evidence on Platform Workers in Europe, Eur. COMM'N, JRC SCI. FOR POL'Y REP. 14 (2020) https://publications.jrc.ec.europa.eu/repository/bitstream/JRC118 570/jrc118570_jrc118570_final.pdf [https://perma.cc/XY55-QPKT].

101. Denis Arsentyev, Get Your Side Hustle On - 'It's Time' | Uber, YouTube (Nov. 23, 2016) https://www.youtube.com/watch?v=3qQJTUYKmYU [https://perma.cc/9TD4-XC2B].

102. Id.

103. Id.

104. The Disrupter Series, supra note 6 (statement of Luceele Smith, Driver/Partner, Uber Technologies, Inc.).

105. Suriano, supra note 10.

106. Hourly guarantees: Another way to earn, UBER FAQ, https://www.uber.com/drive/ pittsburgh/resources/guarantee-faq/ [https://perma.cc/TT3B-MMPY]; How Dasher Pay Works, DOORDASH HELP, https:/help.doordash.com/dashers/s/article/How-is-Dasher-pay-calculated? language $=$ en_US [https://perma.cc/7XLP-4BE8]. 
factors like location, time, distance, desirability, and demand into account. For example, Doordash sets a minimum base pay for each order calculated by the time, distance, and desirability of the order. ${ }^{107}$ Companies like Postmates set location-specific rates for each different aspect of the job like pickups, drop-offs, minutes, and miles. ${ }^{108}$

Other companies let workers set their own rates and take a percentage as a service fee. For example, on Taskrabbit, "Taskers" set an hourly rate for their services; then, Taskrabbit charges $15 \%$ of the total price as a service fee for each completed task. ${ }^{109}$ In cases where companies set a minimum guaranteed pay, tips are a crucial part of income. ${ }^{110}$ Workers report that they often make more money from tips than from the guaranteed minimum pay. ${ }^{111}$ Lucas Grassi is a full-time student who works about 20 hours per week for DoorDash, a groceries and food delivery app, and Postmates, a goods delivery app. ${ }^{12}$ Grassi reports that he expected to make more money than what he currently makes, but the lack of transparency in payments makes it difficult to tell what his take-home pay will be. ${ }^{113}$ Grassi says, "The payment breakdowns he sees on apps after he completes deliveries rarely make it clear . . . how much [customers] tipped, or even if they tipped at all." 114 This lack of clarity has allowed companies to obfuscate their payment policies to decrease workers' earnings. ${ }^{115}$

In February 2019, two DoorDash workers brought a class action lawsuit against the company in the Northern District of Atlanta for breach of contract and unjust enrichment. ${ }^{116}$ The workers claimed that DoorDash had improperly directed tips meant for workers to the company itself. ${ }^{117}$ When a customer orders through the DoorDash app she had the option to leave a tip for the driver in addition to the cost of the order. ${ }^{118}$ DoorDash represented on its website and in marketing materials that drivers would receive base pay plus 100 percent of the tips. ${ }^{119}$ For example, if a driver makes a delivery with a guaranteed minimum of

107. How Dasher Pay Works, supra note 106.

108. Earnings, Postmates FleEt, https://fleet.postmates.com/drive/indianapolis/ earnings [https://perma.cc/U6FD-NKW9].

109. What's the TaskRabbit Service Fee?, TASKRABBIT SuPPORT, https://support.taskrabbit. com/hc/en-us/articles/204411610-What-s-the-TaskRabbit-Service-Fee- [https://perma.cc/M3T5TW7D].

110. Suriano, supra note 10.

111. Id.

112. Id.

113. Id.

114. $I d$.

115. Id.

116. Webb et al. v. Doordash, Inc., Class Action Complaint Case 1:19-cv-00665-CC (Feb. 8, 2019), https://www.classaction.org/media/webb-et-al-v-doordash-inc.pdf [https://perma. cc/M8MXBX6T].

117. Id.

118. Id.

119. Id. at 2 . 
$\$ 5$ and the customer tips $\$ 2$, based on these statements, the driver should expect to receive $\$ 7$. However, in 2017 , the company changed its tipping policy so that the customer's tip is calculated into the base pay. ${ }^{120}$ For example, if a driver makes a delivery with a guaranteed minimum of $\$ 5$ and the customer tips $\$ 2$, the driver will get $\$ 3$ from DoorDash and \$2 from the tip for a total of $\$ 5$. This updated policy varies from the payment policies Uber represented on its website and marketing materials. On August 22, 2019, amidst widespread public scrutiny, DoorDash changed its policy so that the amount it pays in base pay does not vary based on the tip amount. ${ }^{121}$

While DoorDash changed its payment policy, Amazon Flex and Caviar, a company owned by Doordash, still calculate tips into the guaranteed rate of pay. ${ }^{122}$ Other companies engage in different practices that reduce the level of pay workers receive compared to what they expected to earn. ${ }^{123}$ Gig economy workers are in constant competition with each other for pay. ${ }^{124}$ This practice benefits consumers because it pushes workers to work harder, faster, and cheaper. ${ }^{125}$

Many Companies offer intermittent bonuses based on the worker meeting certain goals, for example, a worker could get a bonus for making " $\mathrm{x}$ " number of deliveries in a set period of time. ${ }^{126}$ These bonuses are based on specific data like time, location, demand, and desirability and are calculated with complicated algorithms. Ravenelle, the author of Hustle and Gig: Struggling and Surviving in the Sharing Economy says, "All of the power in the gig economy is held by the platforms. Workers are constantly being rated and ranked, and are competing against each other for pay." Competition amongst workers, "'allows companies to keep workers on their toes without committing to higher pay long-terms . . . And the opaque nature of algorithm-heavy platforms means companies can make incremental changes without raising red flags." $" 127$

Instacart, a grocery delivery service, has been making incremental changes to its algorithm that affect the take-home pay of its workers. Postmates recently eliminated a $\$ 4$ per day guarantee, which drives down workers' earnings. Instacart used to pay delivery workers a flat forty cents per item with opportunities for bonuses. In October 2018, it started to calculate pay based on various factors like the weight of an item, the driving distance, and the grocery

120. Id.

121. Tony Xu, Working to Strike a Better Balance, Doordash Blog (Aug. 22, 2019), https://blog.doordash.com/working-to-strike-a-better-balance-e1 f66c76fca1 [https://perma. cc/9RNQ-9T2Z].

122. Suriano, supra note 10.

123. Abha Bhattarai, Don't Game My Paycheck': Delivery Workers Say They're Being Squeezed by Ever-changing Algorithms, WASH. Post (Nov. 7, 2019), https://www.washingtonpost. com/business/2019/11/07/don't-game-my-paycheck-delivery-workers-say-theyre-being-squeezedby-ever-changing-algorithms/?wpisrc=nl_most\&wpmm=1[https:// perma.cc/Q9CK-6X7Y].

124. Id.

125. See id.

126. Id.

127. Id. 
store the delivery was from. Workers who have been gigging for Instacart in the past few years noticed at least a $30 \%$ decrease in pay over the last year. ${ }^{128}$ These changes speak to one of the strengths of a tech-focused online platform company, which is the ability to use data points to fluctuate with market demands and needs. However, the changes, hidden in a complicated algorithm, also make it difficult for workers to know how much income they will receive.

Workers have a hard time predicting what their paychecks will be next year or even next month. This unpredictability can have serious negative consequences on workers. Ravenelle notes:

British economist Guy Standing warns that this instability has led to the "precariat," a growing number of people "living and working precariously, usually in a series of short-term jobs, without recourse to stable occupational identities or careers, stable social protection or protective regulations." This precariousness often leads to a sense of anxiety, anomie, alienation, and anger. ${ }^{129}$

Although lots of people take on gig work as a supplement to main jobs, the income from gig economy jobs can be crucial for families. ${ }^{130}$ The Federal Reserve found that almost half $(45 \%)$ of gig workers "say that this income is at least somewhat important." Fifteen percent of gig workers report that the income they receive from gigging is very important. ${ }^{131}$ The proportion of people who view the money earned from gig work as an "important source of income for their families," is higher for workers whose education is equivalent or less than a high school degree. ${ }^{132}$

Companies are not required to set a minimum guaranteed rate of pay and are free to change payment policies from one day to the next. As these companies grow and change their policies are likely to change in unpredictable ways.

\section{B. What Hours Do Gig Workers Work?}

Transparency in pay is not the only concern gig economy workers have. Workers for the gig economy generally work "on-demand," which means they do not have set hours rather can choose the hours when they work. ${ }^{133}$ This flexibility is one of the main selling points of working in the gig economy, but it can also be a drawback as "work hours set by employers on short notice may cause financial strain, particularly for low-income workers." "134 Monthly swings in

128. Id.

129. Andrea Ravenelle, Hustle and Gig: Struggling And Surviving in the Sharing ECONOMY 37 (University of California Press 2019).

130. BOARD OF GOVERNORS, supra note 91.

131. Id.

132. Id.

133. See Bhattarai, supra note 123.

134. BoArd of Governors, supra note 91; see also JonAthan Morduch \& RACHel Schneider, The Financial Diaries: How American Families Cope in a World of 
income, even by modest amounts, and unpredictable work hours frequently led to an inability to pay expenses. ${ }^{135}$ In addition, unpredictable hours may make it difficult for part-time workers to take on additional jobs and increase their family income. $^{136}$

Predictable work schedules are important. Schedules and advance notice of shifts can, "affect the economic well-being derived from employment." ${ }^{\text {"137 }}$ Many people who have unpredictable work schedules report that they would prefer a stable schedule even if it meant taking a pay cut. ${ }^{138}$ The Federal Reserve asserts, "Predictable part-time schedules may even support greater labor force engagement, since the predictability would allow workers to seek additional employment and supplement their income." 139 Despite the fact that gig economy workers choose their hours, schedules can still be unpredictable. It can be difficult for a worker to anticipate in advance how many hours they will have to work in a given day to make an adequate paycheck or where their gigs will take them.

TaskRabbit is an online platform that connects skilled workers, called "Taskers," to people who need help with everyday errands or odd-jobs. ${ }^{140}$ When the company first launched its website, it worked as a "bid-focused marketplace, almost an eBay for personal-assistant work." ${ }^{141}$ People who needed a task done for them could post a description of what they needed on the TaskRabbit website. ${ }^{142}$ Then, "rabbits" could "bid" on the work and try to get the job by pitching themselves as the best person for the job. ${ }^{143}$ In 2014, TaskRabbit shifted its model away from the open-bidding format. ${ }^{144}$ Now, workers provide their availability in a four-hour timeframe window. ${ }^{145}$ People looking for workers go on the website, choose a job category, and a timeframe. ${ }^{146}$ Consumers are then able to pick between up to fifteen potential Taskers, who fit the location, category, and time, to do the job. ${ }^{147}$ The worker is required to reply to the request within thirty minutes, or he is in danger of losing the job to another Tasker. ${ }^{148}$ If a worker does not respond in thirty minutes a certain number of times, his

UNCERTAINTY 38-40 (2017).

135. BOARD OF GOVERnors, supra note 91; see also MORDUCH \& SCHNEIDER, supra note 134 , at 34-35.

136. BOARD OF GOVERNORS, supra note 91.

137. Id.

138. $I d$.

139. Id.

140. Revolutionizing Everyday Work, TASKRABBIT.COM, https://www.taskrabbit.com/about [https://perma.cc/3LJX-QGR6].

141. RAVENELLE, supra note 129 , at 55.

142. Id.

143. Id.

144. Id.

145. Id.

146. Id.

147. $I d$.

148. Id. 
account will be temporarily suspended. ${ }^{149}$

For workers who have to deal with many different consumers in one day, planning in advance is almost impossible. ${ }^{150}$ Models, similar to the one Taskrabbit uses, make it difficult to predict work hours. ${ }^{151}$ Yes, the worker signs up for four-hour chunks of time, but there is no way to know what jobs will pop-up, where the jobs will be, or how long it will take to complete the job. The Tasker may get four requests within their designated time-slot; but depending on how far the jobs are from each other and how long each job will take, they might only be able to complete one task. ${ }^{152}$

These types of models are unpredictable for the worker, and they also require the worker to be "on-call" during his four-hour chunk of time or face consequences. ${ }^{153}$ As Ravenelle points out, "if you are financially dependent on an afternoon of work, you may feel like you can't really afford to walk away from the task. By the time a worker arrives at a location, he's likely spent at least an hour on traveling and on communicating with the client."154

Policies that punish workers for rejecting too many jobs diminish one of the most appealing benefits of a gig economy job-choice. In the case of ridesharing apps, drivers can choose to turn the app on or off at any time, but acceptance rates and cancellation rates are monitored. ${ }^{155}$ If a driver rejects too many rides or if they accept a ride and later cancel it, these ratings will go down. ${ }^{156}$ A dip in ratings can lead to the deactivation of the app, meaning drivers are locked out of their employment. ${ }^{157}$ Gig economy workers have little choice of when customers will request work, whom their customers will be, and whether they want to work with a particular customer.

In a similar situation, delivery drivers for Grubhub sign-up to work for blocks of time in a specific area. ${ }^{158}$ Any number of orders could come in during this specific block of time. ${ }^{159}$ In Lawson v. Grubhub, delivery drivers alleged that they should have been compensated for the blocks of time because they were expected to be on-call. ${ }^{160}$ The Court found that the plaintiff had raised a genuine issue of material fact as to whether the driver should be compensated for on-call time

149. Id.

150. See id. at 60 .

151. See id.

152. Id.

153. See id.

154. Id. at 100 .

155. Razak v. Uber Techs., Inc., No. CV 16-573, 2017 WL 4052417, at *7 (E.D. Pa. Sept. 13, 2017).

156. Id.

157. Id. at *14.

158. Lawson v. Grubhub, Inc., No. 15-CV-05128-JSC, 2017 WL 2951608, at*4 (N.D. Cal. July 10, 2017).

159. Id. at $* 6$.

160. Id. at $* 2$. 
because Grubhub controlled his actions. ${ }^{161}$ In the plaintiff's favor, there was the fact that the driver must stay within the designated area and be available for deliveries and that the frequency of the requests was restrictive. ${ }^{162}$ Grubhub argued, in response, that the drivers did not have a typical on-call situation because they could choose to turn the app off whenever they wanted and had no obligation to be on call and complete a task at the will of an employer. ${ }^{163}$ The drivers had the choice to turn the app off and ignore delivery requests. ${ }^{164}$ However, the problem is that pursuant to their service agreement, drivers could be terminated from Grubhub if they were not available during their block of time. ${ }^{165}$

Drivers who brought a claim against Uber for overtime compensation when on call in Razak v. Uber Techs., Inc., argued, "The proposition that online time is not compensable because "transportation providers retain the sole right to determine when, where, and for how long they are online" is a modern version of the Lochner-era argument that repugnant workplace conditions are permissible because of the laborer's' "freedom of contract."' Lochner proposed that because workers had the freedom to enter into contracts and to quit whenever they wanted they were on equal footing with employers and working conditions should not be regulated. ${ }^{166}$ Companies and policymakers balk at regulating virtual marketplace apps because workers have freedom to choose their work assignments. ${ }^{167}$ Proponents of this argument believe that workers are on equal footing with virtual platform companies because of the flexibility they have to turn the app on or off whenever they want. However, this argument ignores some realities.

First, gig economy workers are not on equal footing with the companies that create and facilitate virtual marketplace apps. A driver or tasker or deliverer can choose to turn down undesirable jobs, but if they do, they can be punished with a temporary or permanent ban from using the app. The Court in Holden v. Hardy found,

The proprietors of these establishments and their operatives do not stand upon an equality, and that their interests are, to a certain extent, conflicting. The former naturally desire to obtain as much labor as

161. Id. at *8-9.

162. Id. at *8.

163. Id. at $* 11-12$.

164. Id.

165. Id. at $* 8$.

166. Razak v. Uber Techs., Inc., No. CV 16-573, 2017 WL 4052417, at*7 (E.D. Pa. Sept. 13, 2017); see Lochner v. New York, 198 U.S. 45 (1905), overruled in part by Day-Brite Lighting Inc. v. State of Mo., 342 U.S. 421 (1952), and overruled in part by Ferguson v. Skrupa, 372 U.S. 726 (1963), and abrogated by W. Coast Hotel Co. v. Parrish, 300 U.S. 379 (1937).

167. U.S. Chamber of Commerce Emp't Policy Div., Ready, Fire, Aim How State Regulators are Threatening the Gig Economy and Millions of Workers and Consumers 32 (Jan. 2020). 
possible from their employees, while the latter are often induced by the fear of discharge to conform to regulations which their judgment, fairly exercised, would pronounce to be detrimental to their health or strength. In other words, the proprietors lay down the rules, and the laborers are practically constrained to obey them. In such cases self-interest is often an unsafe guide, and the legislature may properly interpose its authority. ${ }^{168}$

Gig economy workers contractually accept provisions that require them not to turn down gigs. However, they are "induced by the fear" of being suspended or banned from access to apps if they violate these rules. Because of this, workers and the VMC's are not in equal positions of power to contract in self-interest.

Second, workers are not always able to make decisions that benefit their health, safety, and well-being. If a worker encounters a gig that could be dangerous or overtaxing, they might not turn it down because they will lose the time they might have already sunk in the endeavor. ${ }^{169}$ They will also lose out on any earnings they could have made for that time period. ${ }^{170}$ Further, if a worker turns down a gig too many times, he or she can be suspended or terminated from the app and thus lose out on potential future earnings. ${ }^{171}$ As noted above, the income from gigs is very important to many gig economy workers, and their families rely on the money made from gig work. ${ }^{172} \mathrm{~A}$ worker could be hesitant to reject jobs because of the fear of losing access to an app through which he generates an essential portion of his income.

\section{What Agreements Do Gig Economy Workers Make?}

The agreements that most workers sign before they work with gig economy companies resemble terms of service agreements more than employment contracts. ${ }^{173}$ It is likely that workers who are eager to start earning income will quickly click through an agreement with the company they are about to work for without reading it closely. In addition, the agreements are filled with complicated legalese. In one service agreement, Uber reserved "the right, at any time . . . to deactivate or otherwise restrict you from accessing or using the driver app." It also stipulated that "If you do not increase your average rating above the minimum average rating within the time period allowed (if any), [Uber] reserves

168. Holden v. Hardy, 169 U.S. 366, 397 (1898).

169. RAVENELLE, supra note 129 , at 55-62.

170. Id.

171. Id.

172. See discussion infra Section II.B.

173. Georgia Wilkins, The Uber Contract Explained: 'I Would be Loath to Sign It', THE SYdney Morning Herald (May 25, 2016, 10:00 AM), https://www.smh.com.au/business/ workplace/the-uber-contract-explained-i-would-be-loathe-to-sign-it-20160524-gp25vc.html [https://perma.cc/3EEH-DQW4] (quoting Services Agreement, RASIER PACIFIC V.O.F. https://www. theage.com.au/interactive/2016/RASIERPACIFICVOFAgreement AustraliaDecember23.pdf (last updated Dec. 23, 2015) [https://perma.cc/7YBP-BC24]). 
the right to deactivate your access to the driver app." ${ }^{174}$ Workers who sign these agreements may not even know that they can be essentially fired at any moment if they do not meet an arbitrary minimum average rating. ${ }^{175}$ These service agreements can be updated and changed at any time without notice to the worker. ${ }^{176}$ One can imagine any number of onerous stipulations that VMCs could insert into the agreements.

In addition, service agreements that workers sign with VMCs generally include mandatory arbitration agreements. ${ }^{177}$ Workers who have complaints are required to litigate their claims in private arbitration. ${ }^{178}$ This practice keeps issues private, as "Arbitration is, by definition, a private process; arbitration awards will not be made public without the participants' consent."179 The grievances of the plaintiffs in $O^{\prime}$ Connor v. Uber Techs., Lawson v. Grubhub, Razak v. Uber Techs., Inc., and Dynamex Operations West, Inc. v. Superior Court would never have come to light if the plaintiffs had signed mandatory arbitration agreements. ${ }^{180}$ Considering public opinion is currently one of the only pressures on VMCs to change exploitative practices, arbitration agreements keep the power in the hands of companies to make changes to agreements at will. ${ }^{181}$ Further, arbitration decisions do not set precedent. ${ }^{182}$ Even if a worker wins a favorable judgment in arbitration, the decision would have no bearing on the claims of other workers. ${ }^{183}$ In Margaret Jane Radin's book, Boilerplate, she asserts, "[W]hen a firm's massmarket boilerplate withdraws a number of important recipients' rights . . . it is displacing the legal regime enacted by the state with a governance scheme that is more favorable to the firm." 184 Mandatory arbitration agreements deprive workers of access to rights and strips away incentives for employers to follow

174. Id.

175. Id.

176. Id.

177. See The Gig Economy: Using Mandatory Arbitration Agreements with Class Action Waivers, FISHER PHILLIPS (May 1, 2017), https://www.fisherphillips.com/resources-articles-the-gigeconomy-using-mandatory-arbitration-agreements [https://perma.cc/FD8Q-5BN3][hereinafter Fisher PHILLIPS]; Brett Manchel, Beware of Uber's New Terms of Service Agreement, LEVINSON \& Stefani (Jan. 10, 2017), https://levinsonstefani.com/beware-of-ubers-new-terms-of-serviceagreement/ [https://perma.cc/4DTJ-LCVT].

178. See Fisher PhILLIPS, supra note 177.

179. Charlotte Garden, Disrupting Work Law: Arbitration in the Gig Economy, U. CHI. LeGAL F. 205, 208 (2017).

180. O'Connor v. Uber Techs., Inc., 82 F. Supp. 3d 1133 (N.D. Cal. 2015); Lawson v. Grubhub, Inc., No. 15-CV-05128-JSC, 2017 WL 2951608 (N.D. Cal. July 10, 2017); Razak v. Uber Techs., Inc., No. CV 16-573, 2018 WL 1744467 (E.D. Pa. Sept. 13, 2017); Dynamex Operations W. v. Superior Court, 4 Cal. 5th 903 (2018), reh'g denied (June 20, 2018).

181. See discussion supra Section II.A.

182. Garden, supra note 179, at 209.

183. Id.

184. Margaret Jane Radin, Boilerplate: The Fine Print, Vanishing Rights, and the RULE OF LAW 33 (2013). 
existing laws. ${ }^{185}$

\section{NO CONSISTENT, ESTABLISHED RULES TO PROTECT GIG ECONOMY WORKERS}

In the United States, there is no unified view on how gig economy workers should be classified. 29 U.S.C. § 203(e)(1) defines an "employee" as "Any individual employed by an employer," and 29 U.S.C. $\$ 203(\mathrm{~g})$ says that the term "employ," "includes to suffer or permit to work." of information to aid in classification; therefore, questions of employment classification rely greatly on precedent. The existing precedent, expanding on whether a gig-economy worker should be classified as an employee or an independent contractor, varies by jurisdiction. ${ }^{187}$

In Dynamex Operations West, Inc. v. Superior Court, the Supreme Court of California found that delivery drivers for Dynamex should be classified as employees for the purposes of California's wage orders. ${ }^{188}$ This Case signaled that the courts could find that workers for gig economy companies are employees. ${ }^{189}$ In contrast, the Eastern District of Pennsylvania in Razak v. Uber Techs, Inc., decided that UberBlack drivers should be classified as independent contractors within the meaning of the Fair Labor Standards Act. ${ }^{190}$ In a recently published opinion letter, The Department of Labor laid out the reasons why it is in agreement with the Pennsylvania District Court. ${ }^{191}$

\section{A. D.O.L. Opinion}

In April 2019, the Wage and Hour Division of the U.S. Department of Labor published an opinion letter responding to a request from an anonymous VMC that operates an online platform that connects workers to consumers. The anonymous VMC requested an opinion on whether its workers should be classified as employees or independent contractors under the Fair Labor Standards Act (the "FLSA"). ${ }^{192}$ In the letter, the Department of Labor applies a six-factor test to answer whether the service providers working for the VMC are "economically

185. Id.

186. 29 U.S.C. $§ 203(\mathrm{e})(1)(2020) ; 29$ U.S.C. $§ 203(\mathrm{~g})(2020)$.

187. See, e.g., O'Connor v. Uber Techs., Inc., 82 F. Supp. 3d 1133 (N.D. Cal. 2015); Dynamex Operations W. v. Superior Court, 4 Cal. 5th 903, 914-917, 416 P.3d 1, 5-9 (2018), reh'g denied (June 20, 2018).

188. Dynamex Operations $W ., 4$ Cal. 5th 903.

189. Id. After the Court granted summary judgment in favor of Uber the plaintiffs appealed to the Third Circuit Court of Appeals. On March 3, 2020, the Third Circuit held that summary judgment was not appropriate because there were material facts still in dispute. The summary judgment was vacated and remanded. See 951 F.3d 137.

190. Razak v. Uber Techs., Inc., No. CV 16-573, 2017 WL 4052417 (E.D. Pa. Sept. 13, 2017).

191. U.S. Dep't of Labor, Wage \& Hour Div., Opinion Letter (Apr. 29, 2019).

192. Id. 
dependent" on the VMC. ${ }^{193}$ If the service providers are found to be economically dependent, they should be classified as employees; if they are not, they should be classified as independent contractors. ${ }^{194}$

The determination of whether a worker is economically dependent on a potential employer is a "fact-specific inquiry that is individualized to each worker." ${ }^{195}$ Generally, a worker who can work on her own terms is dependent on an employer and the inability of the worker to work on his or her own terms often suggest dependence. ${ }^{196}$ In previous opinion letters, the Wage and Hour Division has evaluated six factors borne from Supreme Court precedent to determine economic dependence:

(1) The nature and degree of the potential employer's control; (2) The permanency of the worker's relationship with the potential employer; (3) The amount of the worker's investment in facilities, equipment, or helpers; (4) The amount of skill, initiative, judgment, or foresight required for the worker's services; (5) The worker's opportunities for profit or loss; and (6) The extent of integration of the worker's services into the potential employer's business. ${ }^{197}$

The DOL applied this Six-Factor Test to the specific facts that the VMC provided and concluded that the workers who utilize the company's online platform are independent contractors.

\section{B. State Opinions}

In Dynamex Operations West, Inc. v. Superior Court, the Supreme Court of California came to a different conclusion than the DOL when the Court evaluated whether delivery drivers were independent contractors or employees for the purposes of California Labor Codes and wage orders. Dynamex is a nationwide same-day delivery service. ${ }^{198}$ In 2004, the company decided to change the classification of its drivers from employees to independent contractors. ${ }^{199}$ As independent contractors, drivers are required to provide their own vehicle and pay for transportation expenses including fuel, tolls, vehicle maintenance, vehicle liability insurance, and taxes and workers' compensation insurance. ${ }^{200}$

193. Id.

194. Id.

195. Id.

196. Id. (Generally referencing Saleem v. Corp. Transp. Grp., Ltd., 854 F.3d 131, 148 (2d Cir. 2017); Scantland v. Jeffry Knight, Inc., 721 F.3d 1308, 1312 (11th Cir. 2013)).

197. Id.

198. Dynamex Operations W. v. Superior Court, 4 Cal. 5th 903 (2018), reh'g denied, (June 20, 2018).

199. Id.

200. Id. 
Dynamex obtains its own customers and sets the rates on delivery services. ${ }^{201}$ Drivers generally set their own schedules but must notify Dynamex on the days they intend to work for the company. ${ }^{202}$ The opinion explains:

On-demand drivers are assigned deliveries by Dynamex dispatchers at Dynamex's sole discretion; drivers have no guarantee of the number or type of deliveries they will be offered. Although drivers are not required to make all of the deliveries they are assigned, they must promptly notify Dynamex if they intend to reject an offered delivery. ${ }^{203}$

The plaintiff in the original complaint brought suit against Dynamex alleging that since 2004 drivers have performed the same tasks in the same manner as when they were classified as employees, and Dynamex failed to comply with the Labor Code and Wage orders by improperly classifying the drivers as independent contractors. ${ }^{204}$ The definition of "employ" set forth in the California Industrial Welfare Commission is "to suffer or permit to work," which is similar to Federal Fair Labor Statute definition. ${ }^{205}$ The Court found that the Commission's language encompasses "all individual workers who can reasonably be viewed as working in the hiring entity's business." ${ }^{206}$ Therefore, it is appropriate to utilize the "suffer or permit to work" standard to distinguish an independent contractor from an employee. ${ }^{207}$

The "suffer or permit to work" standard puts the burden of proof on the hiring entity to establish that a worker is an independent contractor under three factors of an "ABC test." "208 The test asks:

(A) is the worker "free from the control and direction of the hiring entity in connection with the performance of the work?";

(B) does the worker perform work that is "outside the usual course of the hiring entity's business?"; and

(C) is the worker "customarily engaged in an independently established trade, occupation, or business of the same nature as the work performed." 209

The Court concluded that the drivers were employees because Dynamex failed to establish the three elements of the $\mathrm{ABC}$ test. ${ }^{210}$ Like demonstrated here in

201. Id.

202. Id.

203. Id.

204. Id.

205. 29 U.S.C. § 203(e)(1) (2020) ("the term 'employee' means any individual employed by an employer . ..”); 29 U.S.C. § 203(g) (2020) (““Employ’ includes to suffer or permit to work.”).

206. Dynamex Operations $W$., 4 Cal. 5 th at 953.

207. Id.

208. Id. at 956-57.

209. Id. at 957.

210. Id. at 965-67. 
California, half of U.S. states utilize the ABC test to determine whether a worker should be classified as an employee or an independent contractor. ${ }^{211}$

The country is of two minds of whether to classify gig economy workers as employees or independent contractors. Generally, gig workers do not have the training or time to keep track of the nuances of Court decisions and opinions from government agencies. While authorities are working on a cohesive opinion, gig economy workers must continue to do their jobs to earn a paycheck. As a result, companies are able to exploit the confusion and continue to entice workers who find out too late that their side gig does not live up to their expectations.

\section{E.U. DIRECTIVE 2019/1152 ON TRANSPARENT AND PREDICTABLE WORKING CONDITIONS}

The European Union leaves most labor laws to the purview of each individual Member State. ${ }^{212}$ However, the European Union sets certain minimum standards when it comes to matters that uphold social policy such as worker's rights and obligations, information on individual employment, prohibition of discrimination, and health and safety of workers. ${ }^{213}$ The rapid growth of the gig economy outpaced the ability of the European Union to regulate worker's rights in the context of new business concepts and employment models. ${ }^{214}$ Additionally, it was unclear how existing regulations that protect workers should be applied to these new ventures. Member states and cities began to implement "a patchwork of different regulatory actions: some encouraging activity, others restricting it. This results in legal uncertainty for all." ${ }^{215}$

The E.U. Commission recognized the impact the gig economy had on the European Union's economy as a whole. ${ }^{216}$ In its "Single Market Strategy," it recognized the need to implement policies that would "enable the balanced development of the collaborative economy" so that businesses could thrive while workers still enjoyed needed protections. ${ }^{217}$ The Commission developed the European Agenda for the Collaborative Economy (the "Agenda") to research the effect gig economy business models and employment relationships would have

211. Employer or Contractor? The Complete List of Worker Classification Tests by State, WRAPBOOK (Oct. 25, 2019), https://www.wrapbook.com/worker-classification-tests-by-state/ [https://perma.cc/WR64-W29W].

212. See Communication, supra note 14 , at 11.

213. Id.

214. The Single Market Strategy: Enable the Balanced Development of the Collaborative Economy, EuR. COMM'N, https://ec.europa.eu/growth/single-market/strategy_en [https://perma.cc/ E3N4-UGCH] [hereinafter Single Market Strategy].

215. Id.

216. Commission Staff Working Document Accompanying the Document: Communication from the Commission to the European Parliament, The Council, The European Economic and Social Committee and The Committee of the Regions - A European Agenda for the Collaborative Economy, SWD (2016) 184 final (Feb. 6, 2016) [hereinafter Staff Working Document].

217. Id. 
on employers and workers and offer policy guidelines and recommendations. ${ }^{218}$

Concurrently, the European Parliament, the Council, and the Commission proclaimed their commitment to advancing workers' rights with the European Pillar of Social Rights (the "Pillar"). ${ }^{219}$ On November 17, 2017, the European Parliament, the Council, and the European Commission proclaimed the Pillar. ${ }^{220}$ It is a set of twenty principles meant to "reinforce social rights and deliver a positive impact on people's lives in the short and medium term and enable support for European construction in the twenty-first century."221 The European Parliament and the Council incorporated guidelines from the Pillar and research and recommendations from the Agenda to draft E.U. Directive 2019/1152 on Transparent and Predictable Working Conditions. ${ }^{222}$

\section{A. Roots of the E.U. Directive on Transparent and Predictable Working Conditions}

In an economic sense, the European Union is structured as a single territory without borders or regulations that impede the movement of goods or services across the Union. ${ }^{223}$ This structure is known as the "single market."224 The goal of the single market is to, "stimulate[] competition and trade, improve[] efficiency, raise[] quality, and help[] cut prices." 225 However, for the single market to function effectively, there must be a uniformity in how regulations are assessed and implemented. ${ }^{226}$

The Commission noted the challenges of unifying regulations across the European Union in its Single Market Strategy for the collaborative economy. ${ }^{227}$ It announced that it would develop the Agenda to provide "non-binding guidance on, how existing EU legislation applies to collaborative economy business models." 228 The Agenda focused on five key areas, one of which was challenges

218. Id.

219. The European Pillar of Social Rights, Chapter II Fair Working Conditions, EuR. PARL., COUNCIL OF THE EUR. UNION, \& EUR. COMM'N (2017), https://ec.europa.eu/commission/priorities/ deeper-and-fairer-economic-and-monetary-union/european-pillar-social-rights/european-pillarsocial-rights-20-principles_en [https://perma.cc/PK69-FT2Q] [hereinafter Pillar].

220. Proposal for a Interinstitutional Proclamation for the European Pillar of Social Rights, at 25, COM (2017) 251 final (Apr. 26, 2017) [hereinafter Interinstitutional Proclamation].

221. Id. at 4 .

222. See Council Directive 2019/1152, supra note 16.

223. The European Single Market: The Single Market Strategy, Eur. Comm’n, https://ec. europa.eu/growth/single-market_en [https://perma.cc/5YHA-8VUE].

224. Id.

225. $I d$.

226. Id.

227. The Single Market Strategy: Enable the Balanced Development of the collaborative economy, EUR. COMM'N, https://ec.europa.eu/growth/single-market/strategy_en [https://perma.cc/ LCD9-R5PE].

228. Report on a European Agenda for the Collaborative Economy, at 15-16 (Nov. 5, 2017), 
that workers in the collaborative economy might face. ${ }^{229}$ While the gig economy provides new opportunities for self-employed, unemployed, or underemployed people, it can "lead to precarious situations." 230 The Agenda calls on the Commission, Member States, and VMC's "to provide adequate information to platform workers on working and employment conditions and workers' rights, and on their working relationships with both platforms and users," to help avoid putting gig economy workers in precarious situations.

The Agenda also stressed the need to safeguard worker's rights. ${ }^{231}$ It reiterates the need to apply the principles of the Pillar by "stress[ing] the need to ensure that all platform workers ... enjoy the same social and employment rights, [and] the same health and safety protection." 232 Policymakers proclaimed the Pillar because "globali[z]ation, the digital revolution, changing work patterns and societal and demographic developments" have caused swift evolutions in the labor market. ${ }^{233}$ The proclamation notes that all Member States face "significant inequality, longterm and youth unemployment or intergenerational solidarity" in varying degrees. ${ }^{234}$

The Pillar's second chapter focuses on Fair Working Conditions. ${ }^{235}$ Two of the Principles outlined in this chapter are especially relevant to gig economy work. ${ }^{236}$ Principle No. 5 on "secure and adaptable employment" states, "Innovative forms of work that ensure quality working conditions shall be fostered," and, "Entrepreneurship and self-employment shall be encouraged."237 In addition, "Occupational mobility shall be facilitated . . . Employment relationships that lead to precarious working conditions shall be prevented, including by prohibiting abuse of atypical contracts." 238 Pillar No. 7 on "Information about employment conditions" states, "Workers have the right to be informed in writing at the start of employment about their rights and obligations resulting from the employment relationship." 239

The Agenda provides guidance on how existing E.U. law applies to facets of the gig economy. The Commission evaluated the applicable Directive 91/533/EEC, which requires employers to provide certain information to their

\footnotetext{
https://www.europarl.europa.eu/doceo/document/A-8-2017-0195_EN.pdf [https://perma.cc/F9XXZHHA] [hereinafter Report].

229. Id. at 16.

230. Id. at 10-11.

231. Id. at 11 .

232. Id. at 25 .

233. Commission Recommendation on "The European Pillar of Social Rights," 2017 O.J. (L $113 / 56)(9)$.

234. Id.

235. Pillar, supra note 219.

236. Id.

237. Id.

238. Interinstitutional Proclamation, supra note 220, at 6.

239. Id.
} 
employees about the employment relationship. ${ }^{240}$ The evaluation found that the scope of the Directive was not broad enough as it did not "cover all workers in the EU as it allows some noteworthy exemptions and gives Member States the possibility to define whom they consider as 'a paid employee'. ${ }^{241}$ As a result, the Commission proposed a Directive on Transparent and Predictable Working Conditions to Parliament. ${ }^{242}$

\section{B. Directive 2019/1152 on Transparent and Predictable Working Conditions}

On June 20, 2019, the European Parliament passed Directive 2019/1152 on Transparent and Predictable Working Conditions in the European Union. ${ }^{243}$ This Directive was meant to broaden the scope of Directive 91/533/EEC by giving a larger portion of workers the right to receive written information about their employment relationships. ${ }^{244}$ Directive 91/533/EEC remains in force but will be repealed with effect on August 1, 2022, at which time, Directive 2019/1152 will control. ${ }^{245}$ It also incorporates Principle No. 7 of the Pillar to ensure workers who are not in traditional work arrangements be informed about their rights and essential aspects of their employment relationship. ${ }^{246}$ Further, it incorporates Principle No. 5 of the Pillar to promote adaptable and secure employment for all employees. ${ }^{247}$

Directive 2019/1152 attempts to address the challenges that arise from the labor force trending away from traditional employment relationships. ${ }^{248}$ Gig economy workers are seldom in traditional employment arrangements with their

240. Commission Staff Working Document REFIT Evaluation of the "Written Statement Directive" (Directive 91/533/EEC) SWD (2017) 205 final (Apr. 4, 2017) [hereinafter REFIT Evaluation]. Directive 91/533/EEC is commonly known as the "Written Statement" Directive. It "establishes the employer's obligation to inform employees of the conditions applicable to the contract or employment relationship." Employment, Social Affairs \& Inclusion, Working Conditions - Individual Employment Conditions - Written Statement, EuR. COMM'N, https://ec.europa.eu/ social/main.jsp?catId=706\&langId=en\&intPageId=202 [https://perma.cc/7YS6-LTFN].

241. REFIT Evaluation, supra note 240.

242. See generally Proposal for a Directive of the European Parliament and of the Council on Transparent and Predictable Working Conditions in the European Union, COM(2017) 797 final (Dec. 12, 2017) [hereinafter Directive Proposal].

243. Council Directive 2019/1152, 2019 O.J. (L 186) (EU).

244. Id.; Employment, Social Affairs \& Inclusion, Working Conditions - Individual Employment Conditions - Written Statement, supra note 240.

245. Patricia Arias \& Ricardo Acosta, Directive 2019/1152: The European Union Wants Transparent Working Conditions, LuPICINIO INT'L L. FIRM (Sept. 6, 2019), https://www. lupicinio.com/en/the-european-union-wants-transparent-conditions/ [https://perma.cc/H6GH-7B24].

246. Council Directive 2019/1152, supra note 16; Bartłomiej Bednarowicz, Delivering on the European Pillar of Social Rights: The New Directive on Transparent and Predictable Working Conditions in the European Union, 48 InDus. L.J. 4 (Dec. 2019).

247. Council Directive 2019/1152, supra note 16.

248. See generallyid. 
employers. ${ }^{249}$ Non-traditional agreements are often less predictable, and workers are less certain about their rights and social protections. ${ }^{250}$ Therefore, it is even more important for non-traditional workers to be informed about their working conditions. ${ }^{251}$ The Directive calls for "Minimum requirements relating to information on the essential aspects of the employment relationship and relating to working conditions that apply to every worker. . . workers . . . an adequate degree of transparency and predictability." ${ }^{252}$ If the work pattern is "entirely or mostly unpredictable," the employer must inform the worker about the number of guaranteed paid hours, what the remuneration for work performed will be, how much notice will be given before a work assignment, and the deadline for cancellation. ${ }^{253}$ In addition, the worker is not required to work unless the work is within, "predetermined reference hours and days," and appropriate notice was given. ${ }^{254}$ If the employer cancels, after a reasonable deadline, the worker is still entitled to compensation. ${ }^{255}$

Directive 2019/1152 also incorporates the concepts in Principle No. 5 of the Pillar, which prevents employment relationships with precarious working conditions, including the prohibition of abusive atypical contracts. ${ }^{256}$ The Directive limits the "use and duration" of "on-demand" contracts. It also lays out a "Rebuttable presumption of the existence of an employment contract with a minimum [number] of paid hours." In addition, the Directive requires that workers, "benefit from favourable presumptions defined by the Member State, which employers have the possibility to rebut."257

Lastly, Directive 2019/1152 requires Member States to clearly lay out the penalties for infringement of laws adopted pursuant to the Directive, and asserts that the penalties must be "effective, proportionate and dissuasive." 258

\section{IMPLEMENTING E.U. DIRECTIVE 2019/1152 IN THE U.S.}

Virtual marketplace platforms like Uber and TaskRabbit were called "disrupters" when they first launched because they introduced new business concepts and employment models that disrupted entire industries. ${ }^{259}$ The

249. ILR School and The Aspen Institute Future of Work Initiative, What is a Gig Worker?, Gig ECONOMY DATA HuB, https://www.gigeconomydata.org/basics/what-gig-worker [https:// perma.cc/978N-2C6Y].

250. Council Directive 2019/1152, 2019 O.J. (L 186) (EU).

251. Id.

252. Id. art. 6 .

253. Id. art. $4(\mathrm{~m})$.

254. Id. art. 10 .

255. Id.

256. Pillar, supra note 219.

257. Council Directive 2019/1152, supra note 16, art. 15.

258. Id. art. 19.

259. See The Disrupter Series: How the Sharing Economy Creates Jobs, Benefits Consumers, and Raises Policy Questions Hearing Before the Subcomm. On Commerce, Manufacturing, and 
disruption was beneficial because it spurred economic growth and ushered in new ways for workers to earn income. ${ }^{260}$ However, the new employment models did not fit into existing U.S. employment regulations well. ${ }^{261}$ In a similar vein, E.U. Member States were not clear on how existing regulations should be applied to new employment relationships. ${ }^{262}$ Furthermore, there was resistance to VMCs amongst the people and governments of E.U. Member States. ${ }^{263}$

Wary of worker exploitation and unclear about how to apply existing regulations, various E.U. Member States implemented regulations to quell protests and ensure safety and security for their citizens. ${ }^{264}$ However, this caused fragmentation of laws. ${ }^{265}$ The E.U. recognized the tension that the gig economy presented among Member States both as a source of unrest for citizens and as an emerging labor market that did not fit squarely within existing regulations. ${ }^{266}$ Parliament implemented E.U. Directive 2019/1152 as part of a cohesive E.U. strategy to uniformly address challenges that arise from the gig economy, without eliminating the benefits that the companies provide to the economy as a whole. ${ }^{267}$

There are three major challenges that gig economy workers face that the E.U. Directive can help address: (1) the danger of precarious or abusive atypical contracts; (2) the lack of transparency in pay; (3) unpredictable work schedules. A U.S. federal mandate based on the E.U. Directive will address these challenges. First, it will stipulate measures to prevent abuse of "zero-hour" or "on-demand" contracts. Next, it will require companies to be clear and upfront about the nature of the employment relationship. Last, it will require companies to be transparent about all forms of remuneration. The E.U. Directive undoubtedly has some shortcomings, so the proposed mandate will add provisions that go beyond the E.U. Directive. Firstly, the mandate will apply to both employees and independent contractors. Next, to put gig economy workers in a better position, the mandate will require that the burden of proof be on the employer to show that a worker is an independent contractor. Next, it will clarify the definition of a genuine, self-employed person and an independent contractor. Lastly, there will be clear penalties for employers that violate provisions of the mandate.

\section{A. Striking a Balance Between Worker's Rights and the Economy}

E.U. Directive 2019/1152 offers a good roadmap for the United States to follow because it strikes a balance between protecting worker's rights and

Trade of the H. Comm. on Energy and Commerce, 114th Cong. 1 (2015).

260. Id.

261. See discussion supra Sections III.A-B.

262. See The Single Market Strategy, supra note 214.

263. See Topping, supra note 61; Rubin \& Scott, supra note 64; Dent, supra note 66.

264. See The Single Market Strategy, supra note 214.

265. Id.

266. See Communication, supra note 14.

267. Council Directive 2019/1152, supra note 16. 
enabling businesses to grow and entrepreneurial ideas to sprout. ${ }^{268} \mathrm{~A}$ federal mandate that incorporates portions of the E.U. Directive would offer protections to workers while maintaining the benefits that arise from gig economy employment. The mandate would act as a guidepost for states to uniformly protect gig economy workers but not be so rigid as to ignore the different demographic, cultural, and political make-up of different U.S. states. The mandate would allow states to enact policies that provide further protections to gig workers, but states would not be able to go below the threshold of minimum rights stipulated in the mandate. Hence, the mandate would create uniformity while allowing for flexibility.

E.U. Directive 2019/1152 stresses the importance of maintaining the "reasonable flexibility of non-standard employment." ${ }^{269}$ This is important because flexibility is one of the main benefits of the gig economy to workers and employers. ${ }^{270}$ The fact that the European Parliament issued a directive on the gig economy rather than a binding regulation also promotes flexibility. The Directive sets guidelines, and Member States are free to create laws that adhere to the demographic, cultural, and political makeup of their State. ${ }^{271}$ For example, Italy has a high proportion of people who work in the service sector. ${ }^{272}$ As gig economy jobs are often geared towards the service sector, Italy might choose to impose stricter restrictions to protect the rights of workers. Additionally, in France, most people participate in "platform working" to earn supplemental income; therefore, France may choose to just meet the threshold of protections because their workers are less reliant on income from gig economy positions. ${ }^{273}$

A U.S. federal mandate would also grant flexibility to states to decide the level of protection to provide workers. Various factors, such as rural versus urban population, unemployment rates, political makeup of the state, and the number of people working in the service sector could affect decisions that the states make on regulations. An urban center like New York City provides more opportunities for workers to work in the gig economy. Already, New York has imposed strict regulations on gig economy work, which would not be feasible in less populated areas with less demand for gig work. ${ }^{274}$ A federal mandate, like the E.U. Directive, allows flexibility, which helps maintain a balance between protecting

268. Id.

269. Id. $\S 6$.

270. $I d$.

271. Directorate General for Internal Policies: Policy Department A: Economic and Scientific Policy, The Social Protection of Workers in the Platform Economy: Annex, at 22 (2017), http://www.europarl.europa.eu/RegData/etudes/STUD/2017/614184/IPOL_STU(2017)614184( ANN01)_EN.pdf [https://perma.cc/5AHY-XJAC].

272. Id.

273. Id. at 12.

274. Anna Sanders \& Clayton Guse, NYC to Impose Some of the World's Toughest Regulations on Uber and Lyft, N.Y. DAILy News (June 12, 2019, 1:37 PM), https://www. nydailynews.com/new-york/ny-uber-lyft-cap-fhv-regulations-tlc-20190612pspo2afygje63mxm4lr55s57jq-story.html [https://perma.cc/K9VX-U3B6]. 
workers, preserving the benefits of the gig economy and allows states to pass regulations that fit their particular makeup.

In its proposal to European Parliament for Directive 2019/1152, the Commission noted that their evaluation revealed weaknesses in the "personal and material scope" of Directive 91/533/EEC. ${ }^{275}$ Yet, the Commission still incorporated the principles of transparency from Directive 91/533 in the proposal because it was popular and effective. ${ }^{276}$

The REFIT evaluation showed a medium to high Member State compliance with the Directive. ${ }^{277}$ The evaluation also revealed that the objectives of Directive 91/533/EEC were considered relevant by all stakeholders including employees, employers, and trade unions. ${ }^{278}$ Stakeholders agreed that the Directive made "an important contribution to ensuring that employees are aware of their rights and protected against possible infringement of those rights." ${ }^{.279}$ The Directive's goals of transparency and worker protection were also considered to be important and relevant to "atypical" forms of employment like gig economy work. ${ }^{280}$

The evaluation also showed that the Directive was effective in carrying out its objectives. Employees and employers were positively impacted because the Directive:

(1) "Increased awareness and understanding among employees of the essential aspects of their working conditions and rights;",

(2) "Increased certainty and clarity for both employers and employees on what has been agreed;" and

(3) "Reduced information asymmetries between employers and employees."281

A worker who is informed of his rights is able to assert them, and informed employers know when they are stepping over the line. Directive 2019/1152 was recently proclaimed, and countries are not required to implement it until 2022. However, data showing the relevance and effectiveness of Directive 91/533/EEC suggests that Directive 2019/1152 will be effective in its goals to increase transparency and protect workers. ${ }^{282}$

\section{B. The Need for Transparency with Gig Economy Work}

The nature of gig economy work, and indeed one of its major selling points, is its flexibility. Gig workers can choose to work when and where they want. Relatedly, companies are under no obligation to give gig economy workers hours

275. Directive Proposal, supra note 242.

276. See Id.; REFIT Evaluation, supra note 240.

277. REFIT Evaluation, supra note 240 at 3.

278. Id. at 19.

279. Id.

280. Id. at 21 .

281. Id. at 22 .

282. Id. at 19. 
or guaranteed pay for any of the hours they work. Agreements that workers sign are unclear and sometimes unfair. ${ }^{283}$ Agreements may include clauses that give VMC's the right to change the terms and conditions of the agreement at any time or to restrict access to the apps at any time. ${ }^{284}$ Further, it is very common for VMCs to include mandatory arbitration agreements in their service agreements. ${ }^{285}$ These stipulations prevent public disclosure of workers' grievances and disincentivizes companies to implement fair hour and wage practices. ${ }^{286}$ The lack of clarity can make it difficult for workers to determine their actual pay. It can also prevent VMCs from being held accountable for changes to pay structures. Uncertain schedules leave workers in a precarious position. Furthermore, a lack of transparency can lead to abuses of gig-economy type agreements.

\section{i. Transparency in Pay}

Some companies have taken the initiative to provide more transparency in how their workers will be remunerated. ${ }^{287}$ However, as in the case of DoorDash, many companies only became transparent in response to public backlash. In addition, complicated algorithms make it difficult for workers to know what they will be paid for each delivery or ride. Unless there is a public outcry, there is nothing to stop companies from hiding exploitative pay practices within a complicated algorithm. ${ }^{288}$ E.U. Directive 2019/1152 addresses the challenges that gig economy workers face in determining income. The Directive states, "Information on remuneration to be provided should include all elements of the remuneration indicated separately, including, if applicable, contributions in cash or kind, overtime payments, bonuses and other entitlements, directly or indirectly received by the worker in respect of his or her work." 289

Companies should be as upfront and clear as possible on all forms of payment and how they are broken down between guaranteed rates and tips. The U.S. federal mandate should have a provision similar to Article 20 of the E.U. Directive 2019/1152. Such a proposal will require companies to lay out in clear terms the compensation a worker received for a gig performed. Moreover, it should also require a clearly broken out distinction among base pay, tips, and other compensation (i.e., mileage compensation).

\section{ii. Transparency to Prevent Abuse of Gig Economy Agreements}

The agreements that workers sign are unclear and sometimes unfair. ${ }^{290}$ Workers do not have contracts; instead, they sign documents more akin to terms

283. Wilkins, supra note 173.

284. Id.

285. See discussion supra Section II.D.

286. Id.

287. See discussion supra Section II.A.

288. Id.

289. Council Directive 2019/1152, supra note 16.

290. Wilkins, supra note 173. 
of service agreements that are littered with confusing language and, in most cases, include mandatory arbitration agreements. E.U. Directive 2019/1152 recognizes that workers who have no guarantees of hours or pay are in a precarious situation, and this situation can be easily exploited. The United States can implement a policy that echoes the E.U. Directive by stipulating that companies must provide clear and understandable information on the nature of the employment relationship to workers before they start working.

Three provisions should be adapted from E.U. Directive 2019/1152 to prevent abuse of on-demand agreements. First, Article 29 of the E.U. Directive, which states:

An employer cannot prohibit workers from working for other employers outside the work schedule established with that employer or subject the worker from adverse treatment for doing so. States may lay down conditions for the use of incompatibility restrictions on working for other employers for objective reasons, such as for the protection of the health and safety of workers including by limiting working time, the protection of business confidentiality, the integrity of the public service or the avoidance of conflicts of interests. ${ }^{291}$

Employers should only prohibit workers from working for different employers if there is a legitimate interest such as health, safety, conflict of interest, or protection of proprietary information.

Second, Article 33:

Workers should have the possibility to refuse a work assignment if it falls outside of the reference hours and days or if they were not notified of the work assignment in accordance with the minimum notice period, without suffering adverse consequences for this refusal. Workers should also have the possibility to accept the work assignment if they so wish. ${ }^{292}$

In conjunction with Article 34: "a worker whose schedule is mostly or entirely unpredictable who has agreed with her employer to do a specific work assignment she should be adequately compensated in income if there is a late cancellation of the assignment." Companies should be prohibited from punishing workers, for example, by downgrading their rating or turning off their app, if they refuse certain work assignments. The policy should also stipulate that workers should be compensated when they are on-call, when their app is switched on, and they are actively looking for work.

Last, the mandate should require companies to remunerate a worker if an assignment is canceled at late notice, or as stated in Article 35:

On-demand contracts under which the employer has the flexibility of calling the worker to work as and when needed, are particularly unpredictable for the worker. States should work to prevent the abuse of

291. Council Directive 2019/1152, supra note 16.

292. Id. art. 33. 
the contracts. Such measures could take the form of limitations to the use and duration of such contracts, of a rebuttable presumption of the existence of an employment contract or employment relationship with a guaranteed number of paid hours based on hours worked in a preceding reference period, or of other equivalent measures that ensure the effective prevention of abusive practices. ${ }^{293}$

This Proposed Mandate will give states the power to enact policies that will prevent the abuse of flexible, gig economy agreements. The states can limit the use and duration of these agreements. A state can also choose to enact a rebuttable presumption of the existence of an employment contract based on hours worked in an earlier period.

\section{Expanding on the E.U. Directive 2019/1152}

One critique of the E.U. Directive 2019/1152 is that it does not go far enough to cover workers who are considered independent contractors. ${ }^{294}$ This is an especially problematic in the United States where there is a disagreement among states and between states and the federal government on whether gig economy workers should be classified as employees or independent contractors. ${ }^{295}$ The dispute should not be resolved by a blanket decision made by the federal government declaring gig economy workers to be employees or independent contractors because the overall situation for the workers may vary from state to state. However, this mandate should put gig workers in a better position in relation to companies, so they can feel more secure in their work. Expanding upon the E.U. Directive a U.S. mandate should (1) apply to both independent contractors and employees, (2) specify that the burden of proof is on the employer to show that the worker is an independent contractor, and (3) stipulate strict penalties for misclassification of workers.

Some scholars argue that rather than passing laws to classify gig economy workers as employees or independent contractors, the federal government should extend minimum protections to all workers regardless of their classification. ${ }^{296}$ This extension of certain rights is not unheard of, "legislation has already extended certain speech rights, for example whistleblowing and anti-retaliation protections under financial statutes like Dodd-Frank and Sarbanes-Oxley, to all workers." ${ }^{297}$ The government put these types of protections in place so that employers can't attempt to deny workers their statutorily protected rights. ${ }^{298}$ Extending a set of minimum protections to all workers, will prevent employers from classifying more and more workers as independent contractors as a workaround for providing reasonable protections.

293. Id. art. 35 .

294. See Bednarowicz, supra note 246.

295. See discussion supra Section III.

296. See Lobel, supra note 30, at 63.

297. Id.

298. Id. 
Gig economy workers and VMCs are not on equal footing. ${ }^{299}$ Workers face major hurdles if they want to show that they were misclassified by their employers. VMCs deploy lobbying efforts in the millions of dollars to prevent statutory protections from passing. ${ }^{300}$ They have robust legal teams and millions of dollars in capital to allocate towards legal defenses. ${ }^{301}$ Further, workers may sign arbitration agreements that keep them from even getting to the litigation stage. ${ }^{302}$ If a worker is able to reach trial on a misclassification claim, they should be given some kind of advantage to balance out the scales. There should be an assumption that the worker is an employee, and the burden of proof should be on the employer to show that the person is an independent contractor. Further, there should be strict penalties on misclassification to deter employers from misclassifying their workers.

\section{Why a Federal Mandate?}

Currently, there is no federal legislation aimed at protecting gig economy workers. The question of how to classify a gig economy worker is still left up to the courts of each state. A federal mandate that provides minimum protections to gig economy workers would put workers from different states on equal footing and prevent workers with less bargaining power from being exploited. As California's AB-5 takes effect, California-based freelance journalists and photographers fear that their gigs would be outsourced to workers in other states. ${ }^{303}$ When worker protections are legislated state by state, companies are able to "shop around" for workers in other states who are guaranteed fewer protections. ${ }^{304}$

Virtual marketplace platforms generally connect consumers and workers at

299. See discussion supra Section II.B.

300. Alex Rosenblat, Uber's Drive-By Politics, Motherboard Tech by Vice (May 27, 2016, 10:15 AM), https://www.vice.com/en_us/article/gv5jaw/uber-lyft-austin-drive-by-politics [https:// perma.cc/UC82-YPLL]; Kate Conger, Uber, Lyft, and DoorDash Pledge $\$ 90$ Million to Fight Driver Legislation in California, N.Y. TIMES (Aug. 29, 2019), https://www.nytimes.com/2019/ 08/29/technology/uber-lyft-ballot-initiative.html [https://perma.cc/ECX3-RXV5].

301. See Conger, supra note 300.

302. See Garden, supra note 179 , at 208-09.

303. California Assembly Bill 5 (AB-5) codifies the Dynamex decision, which puts the burden of proof on the hiring entity to establish three factors of an " $\mathrm{ABC}$ test" to show that the worker is an independent contractor. The employer must show: (A) that the worker is "free from the control and direction of the hiring entity in connection with the performance of the work;" (B) that the worker performs work that is "outside the usual course of the hiring entity's business;" and (C) that the worker is "customarily engaged in an independently established trade, occupation, or business of the same nature as the work performed." AB-5; Dynamex Operations W. v. Superior Court, 4 Cal. 5th 903 (2018), reh'g denied (June 20, 2018).

304. Michael Hiltzik, Colum: Freelancers Fear California's New Gig Worker Law Will Wipe Them Out, L.A. Times (Oct. 25, 2019, 6:00 AM), https:/www.latimes.com/business/ story/201910-25/hiltzik-freelance-writers-gig-worker-law [https://perma.cc/K3JD-Q8P9]. 
a local level because the workers provide physical services. For example, Uber and Lyft cannot utilize drivers from other states to pick up passengers in Los Angeles or San Francisco - two of their largest markets. ${ }^{305}$ However, companies have begun to develop platforms that connect consumers with workers who can provide intellectual work remotely. ${ }^{306}$ For example, Amazon Mechanical Turk is a virtual marketplace company that connects employers with workers who can perform jobs remotely. ${ }^{307}$ With virtual communication, the worker could be based in any state. State-by-state worker protections could drive companies towards cherry-picking workers from states that do not provide protection.

\section{CONCLUSION}

The gig economy has greatly impacted the labor force and has continued to change and evolve in the past decade since it began. Virtual marketplace companies are largely unregulated and therefore are able to shift and change policies to better the position of the company. Sometimes this comes at the expense of the worker. E.U. Directive 2019/1152 emphasizes transparency in balancing the needs of employers and workers. It also offers a roadmap for the United States to follow while protecting workers who are part of the "gig economy." The United States should incorporate portions of the E.U. Directive and expand beyond the E.U. Directive's protections in a federal mandate with a minimum set of rights for all workers. Workers deserve to have clear and upfront information about the nature of the employment relationship, have transparency about all forms for remuneration, and not be exposed to exploitative or abusive contracts.

305. Id.

306. See Bob Ambrogi, Launching Soon: 'Text A Lawyer' Aims To Be The Uber Of Legal Help, LAwSites (June 20, 2018), https://www.lawsitesblog.com/2018/06/launching-soon-textlawyer-aims-uber-legal-help.html_[https://perma.cc/V4VA-JNXV].

307. Amazon Mechanical Turk, MTURK.COM, https://www.mturk.com [https://perma.cc/CP2Z69SG]. 